\title{
Anatomia foliar de Barnebya (Malpighiaceae), um gênero endêmico do Brasil
}

\author{
Leaf anatomy of Barnebya (Malpighiaceae), an endemic genus of Brazil \\ Anatomía foliar de Barnebya (Malpighiaceae), un género endémico de Brasil
}

Received: 01/17/2022 | Reviewed: 02/04/2022 | Accept: 02/22/2022 | Published: 03/03/2022

\author{
Rafael Ribeiro de Matos \\ ORCID: https://orcid.org/0000-0002-7764-2998 \\ Universidade Estadual do Piauí, Brasil \\ E-mail: rafael.matos@ufv.br \\ Natânia Pereira Pinto da Silva \\ ORCID: https://orcid.org/0000-0003-2839-8367 \\ Universidade Estadual do Piauí, Brasil \\ E-mail: natania3105@gmail.com \\ Josiane Silva Araújo \\ ORCID: https://orcid.org/0000-0002-2629-8306 \\ Universidade Estadual do Piauí, Brasil \\ E- mail: josianesilva@cpm.uespi.br
}

\begin{abstract}
Resumo
O estudo apresenta a descrição anatômica foliar de Barnebya, um gênero endêmico do Brasil com apenas duas espécies. $\mathrm{O}$ objetivo deste trabalho foi descrever a anatomia foliar e identificar características diagnosticas para a taxonomia e sistemática deste gênero. Folhas herborizadas das espécies B. dispar (Griseb.) WR Anderson \& B. Gates e B. harleyi WR Anderson \& B. Gates foram reidratadas e processadas de acordo com os métodos anatômicos usuais para análise em microscopia de luz. Os caracteres anatômicos foliares diagnósticos são: a presença e o número de feixes acessórios no pecíolo, conformação do feixe vascular da nervura central, presença de tricomas, presença de ornamentação na parede externa de células epidérmicas na face abaxial do limbo foliar e os tipos de monocristais. Os resultados obtidos no presente estudo mostraram e ressaltam que caracteres anatômicos relacionados a pecíolos são importantes na caracterização de gêneros e caracteres relacionados a lâminas foliares são importantes na caracterização de espécies em Malpighiaceae, corroborando estudos anteriores e realizando pela primeira vez a descrição anatômica foliar de Barnebya.
\end{abstract}

Palavras-chave: Clado Barnebioide; Glândulas foliares; Flora neotropical; Anatomia vegetal.

\begin{abstract}
The study presents the leaf anatomical description of Barnebya, an endemic genus from Brazil with only two species. The objective of this work was to describe the leaf anatomy and identify diagnostic features for the taxonomy and systematics of this genus. Herborized leaves of the species B. dispar (Griseb.) WR Anderson \& B. Gates and B. harleyi WR Anderson \& B. Gates were rehydrated and processed according to the usual anatomical methods for light microscopy analysis. The diagnostic leaf anatomical characters are: the presence and number of accessory bundles on the petiole, conformation of the vascular bundle of the midrib, presence of trichomes, presence of ornamentation on the outer wall of epidermal cells on the abaxial face of the leaf blade and the types of single crystals. The results obtained in the present study showed and emphasize that anatomical characters related to petioles are important in the characterization of genera and characters related to leaf blades are important in the characterization of species in Malpighiaceae, corroborating previous studies and performing for the first time the anatomical description of leaves of Barnebya.
\end{abstract}

Keywords: Barnebyoid clade; Leaf glands; Malpighiales; Neotropical flora; Plant anatomy.

\section{Resumen}

El estudio presenta la descripción anatómica de las hojas de Barnebya, un género endémico de Brasil con sólo dos especies. El objetivo de este trabajo fue describir la anatomía foliar e identificar características diagnósticas para la taxonomía y sistemática de este género. Hojas herborizadas de las especies B. dispar (Griseb.) WR Anderson \& B. Gates y B. harleyi WR Anderson \& B. Gates se rehidrataron y procesaron de acuerdo con los métodos anatómicos habituales para análisis de microscopía de luz. Los caracteres anatómicos foliares diagnósticos son: presencia y número de haces accesorios en el pecíolo, conformación del haz vascular de la nervadura central, presencia de tricomas, presencia de ornamentación en la pared externa de células epidérmicas en la cara abaxial de la lámina foliar y los tipos de monocristales. Los resultados obtenidos en el presente estudio mostraron y enfatizan que los caracteres anatómicos relacionados con los pecíolos son importantes en la caracterización de géneros y los caracteres relacionados con las láminas foliares son importantes en la caracterización de especies en Malpighiaceae, 
corroborando estudios previos y realizando por primera vez las características anatómicas. descripción de hojas de Barnebya.

Palabras clave: Clado Barnebioide; Glândulas foliares; Flora Neotropical; Anatomía vegetal.

\section{Introduction}

Barnebya W. R. Anderson \& B. Gates is a native and endemic genus of Brazil, its systematic position in Malpighiaceae is discussed especially because it is similar in some aspects to the subfamily Byrsonimoideae and in other aspects to the Old-World genus Acridocarpus (Anderson, 1993). Two species are recognized, B. dispar (Griseb.) WR Anderson \& B. Gates and B. harleyi WR Anderson \& B. Gates, which occur in humid forests and caatingas in the states of Piauí, Pernambuco and São Paulo (BFG, 2015). Their representatives are classified as trees with alternating leaves or opposite ones with glands on the abaxial face. Perennial flowers with bilaterally symmetrical corolla; yellow petals, dried fruit, separated into two types: pyramidal toroid chamber and chamber with an elongated dorsal wing thickened on the adaxial margin, number of chromosomes: $\mathrm{n}=30$ (Anderson, 1981).

The inflorescence of the cincinnus type resembles those from the genera of the Mcvaughia genera and genera of byrsonimoide clade. Similarly, radially porous and symmetrical pollen suggests the derivation of colporate pollen found in the Mcvaughia genera and in the byrsonimoide clade. The types of fruit resemble those characteristic of the Banisteriopsis C.B.Rob. ex. Small, and Stigmaphyllon A. Juss and similar genera, but unlike these genera Barnebya has its carpels largely conical (Anderson, 1981).

Due to its similarity in the flowers morphology, inflorescence type, pollen and fruits of other genera, in addition to being morphologically enigmatic as to its location by DNA, leaf anatomy applied to taxonomy emerges as an excellent tool to improve the delimitation of species in genera with intricate taxonomy, such as Barnebya, as well as being an alternative to indicate evolutionary trends and phylogenetic relationships among taxa. For Malpighiaceae, promising results with this type of approach were obtained for leaves of different genera such as Amorimia W. R. Anderson, Banisteriopsis C. B. Rob. ex. Small, Byrsonima Rich. ex Kunth, Camarea A.St.-Hil, Heteropterys Kunt and Stigmaphyllon A.Juss. (Mamede, 1987; Araújo et al., 2010; Almeida et al., 2017; Almeida et al., 2019; Mello et al., 2019; Araújo et al., 2020; Santos et al., 2020; Matos \& Araújo, 2021).

Thus, the present work aims to carry out an anatomical description of the leaves of Barnebya species, seeking anatomical and micromorphological characters capable of identifying the species studied, improving the taxonomy and systematics of the genus. In addition to providing characters capable of improving the understanding between Barnebya and the other clades of Malpighiaceae.

\section{Material and Methods}

There were analyzed leaves from two species of Barnebya, representing all species currently accepted in the genus according to Anderson and Gates (1981) (Table 1). All leaves were obtained from exsiccates deposited in Brazilian herbariums (BHCB, HUEFS, VIC, SPF and VIES), acronyms of Thiers (2019). Fully expanded and well-preserved leaves were sampled. The leaves were rehydrated in boiling distilled water until completely submerged (in five to fifteen minutes, in general), soaked in $2 \% \mathrm{KOH}$ solution for total distention (two hours in general), washed and dehydrated in a series of ethyl alcohol and stored in $70 \%$ ethanol. All specimens were freehand sectioned with the aid of a razor blade to obtain transverse and longitudinal sections of the leaf blade (base, middle and apex) and petiole. The median region was adopted for anatomical descriptions since there were no significant differences among the sectioned portions of the leaf blade. The cuts were clarified in $20 \%$ sodium hypochlorite and stained in basic fuchsin - Astra blue, and the slides mounted in glycerin gelatine and sealed 
with clear polish (Kraus \& Arduin, 1997). Vascular bundles and the venation pattern were classified according to Howard (1979) and Ellis et al. (2009), respectively. The types of trichomes were classified according to Theobald et al. (1979).

Table 1. List of Barnebya species and vouchers analyzed in this study.

\begin{tabular}{ll}
\hline \multicolumn{1}{c}{ Species } & \multicolumn{1}{c}{ Collector/number (herbarium) } \\
\hline Barnebya dispar (Griseb.) W.R. Anderson \& B.Gates & M.G. Bovini 2168 (SPF) \\
& L.D. Thomaz 1043 (VIES) \\
& G. Martinelli 4592 (VIES) \\
\hline Barnebya harleyi W.R. Anderson \& B.Gates & L.P. Queiroz 14568 (HUEFS) \\
& E. Melo 11563 (HUEFS) \\
& J.F. Carrión 1590 (VIC) \\
& P.H.A. Pequeno 215 (BHCB) \\
\hline
\end{tabular}

Source: speciesLink.

Part of the samples was diaphanized according to Foster (1950). The samples were kept in sodium hydroxide solution for two hours, washed several times in distilled water and then kept in $20 \%$ sodium hypochlorite for 18 hours or until the tissue becomes translucent. Soon after, the samples were washed and dehydrated in a series of ethyl alcohol (10\%-50\%) and stained with $50 \%$ alcoholic fuscin, the slides were mounted in glycerin gelatin and sealed with clear varnish. The analyzes and photographs were made using a photomicroscope (Olympus AX70TRF, Olympus Optical, Tokyo, Japan) with U-Photo system with a digital camera attached (AxioCam HRc; Zeiss, Göttingen, Germany). An epifluorescence application (HBO 50-W) was also used, with a mercury lamp and excitation filter BP 340-380, 459 dichroic mirrors and LP-430 filter (Ushio-USH 102D, Japan).

Finally, compare the species through a multi-state character matrix (Table 2) for the elaboration of the identification key.

Table 2. Multistate characters matrix: A. Petiole contour, type: (0) biconvex, (1) convex plane; B. Trichomes in the petiole: (0) presence, (1) absence; C. Cuticle type in the petiole: (0) thick, (1) thin; D. Petiole epidermis type: (0) unistratified, (1) bistratified; E. Accessory bundles in the petiole: (0) One pair, (1) Two pairs; F. Conformation type of the vascular bundles in the petiole: (0) convex plane, (1) biconvex; G. Sclerenchyma around the vascular bundles of the petiole: (0) presence, (1) absence; H. Druses in the petiole: (0) presence, (1) absence; I. Prismatic crystals in the petiole: (0) presence, (1) absence; J. Midrib contour type: (0) biconvex, (1) convex plane; K. Conformation type of the vascular bundles of the midrib: (0) convex plane, (1) biconvex; L. Sclerenchyma around the vascular bundles in the midrib: (0) presence, (1) absence; M. Mesophyll type: (0) dorsiventral, (1) isobilateral; N. Prismatic crystals in the midrib vein: (0) presence, (1) absence; O. Sheath extension in the mesophyll: (0) presence, (1) absence; P. Variation of the space between the adjacent secondary type: (0) decreasing proximal, (1) irregular; Q. Quinternary veins: (0) presence, (1) absence; R. Marginal veins forming looped: (0) Absence, (1) presence.

\begin{tabular}{lllllllllllllllllll}
\hline & $\mathbf{A}$ & $\mathbf{B}$ & $\mathbf{C}$ & $\mathbf{D}$ & $\mathbf{E}$ & $\mathbf{F}$ & $\mathbf{G}$ & $\mathbf{H}$ & $\mathbf{I}$ & $\mathbf{J}$ & $\mathbf{K}$ & $\mathbf{L}$ & $\mathbf{M}$ & $\mathbf{N}$ & $\mathbf{O}$ & $\mathbf{P}$ & $\mathbf{Q}$ & $\mathbf{R}$ \\
\hline B. dispar & 0 & 0 & 0 & 0 & 0 & 0 & 0 & 0 & 1 & 0 & 1 & 0 & 0 & 1 & 1 & 0 & 1 & 1 \\
B. harleyi & 0 & 0 & 0 & 0 & 1 & 0 & 0 & 0 & 0 & 0 & 0 & 0 & 0 & 0 & 0 & 1 & 0 & 1 \\
\hline
\end{tabular}




\section{Results}

The species showed, in a cross-section, contour of the biconvex petiole, deciduous trichomes, thick cuticle, unistratified epidermis, druses, fibers surrounding the vascular bundle and conformation of the vascular bundle convex plane type (Fig. 1A-B). In B. dispar, a pair of accessory bundles (Figure 1B) was observed while B. harleyi had two pairs of accessory bundles and prismatic crystals (Figure 1B-C).

Regarding the median region of the leaf blade, some characteristics, such as the biconvex contour, unistratified epidermis on both sides and fibers, were common to all specimens (Figure 1D-E). B. díspar presented deciduous trichomes and conformation of the biconvex vascular bundle (Figure 1D), whereas in B. harleyi the trichomes were absent and the conformation of the vascular bundle was of the convex plane type (Figure 1E).

Regarding the mesophyll, both had the dorsiventral type, present druses, and stomata only on the abaxial face of the leaf blade, being on the same level as the epidermal cells presenting stomatal ridges (Figure 1F-I). B. harleyi showed sheath extension and arrangements on the outer wall of the epidermal cells on the abaxial face (Figure 1H-I). All the species analyzed showed sessile glands with a concave surface on the abaxial face of the leaf blade (Figure 2A-B).

\section{Figure 1.}

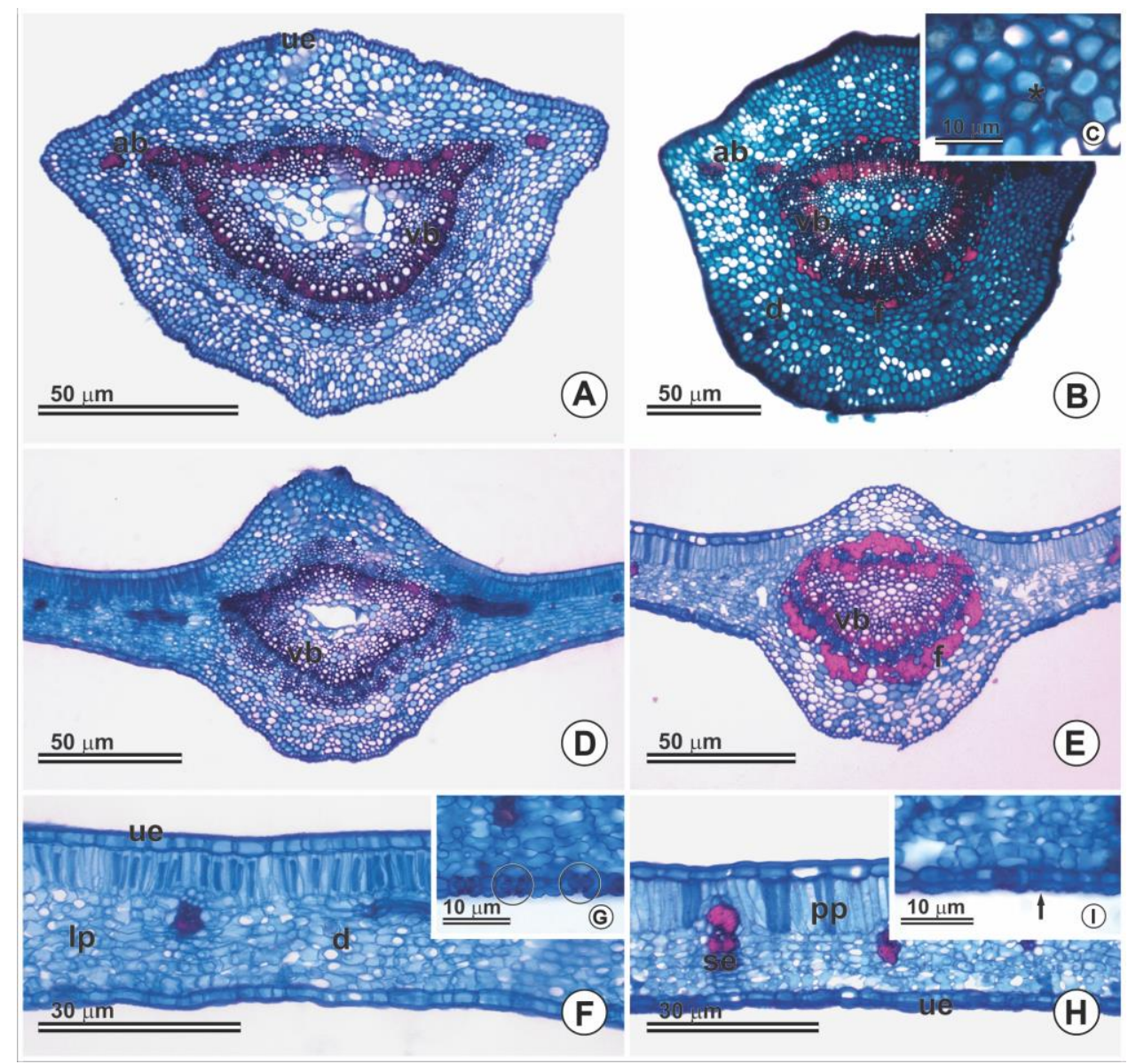

Source: Authors

As for the venation pattern, the species were pinnate, with absent basal veins, the secondary veins divided and did not reach the margin forming a simple broquidodrome pattern, mixed secondary and interior secondary veins were absent (Figure 2C-D). In B. dispar the variation of the space between the adjacent secondary was of the proximal decreasing type, the course 
of the proximal and distal intersecundary veins was perpendicular and the quinternary veins absent (Fig. 2C), whereas in $B$. harleyi the variation of the space among the adjacent secondary ones it was of the irregular type, the course of the proximal intersecondary veins is parallel to the major secondary, and the distal reticulated or branched with quaternary veins of the irregular reticulated type and quinternary loosely branched (Fig. 2D). The species showed a good state of areolation, and the last marginal veins formed loops (Fig. 2C-D).

Figure 2. Glands detail and diaphanization: A. Concave sessile gland (Arrow) in Barnebya harleyi; B. Concave sessile gland (Arrow) in Barnebya dispar; C. Detail of the venation in Barnebya dispar; D. Detail of the venation in Barnebya harleyi. $1^{\circ}=$ Primary rib; $2^{\circ}=$ Secondary rib; $3^{\circ}=$ Tertiary rib; $4^{\circ}=$ Quartenary rib; $5^{\circ}=$ Fifth rib; $*=$ Loops.

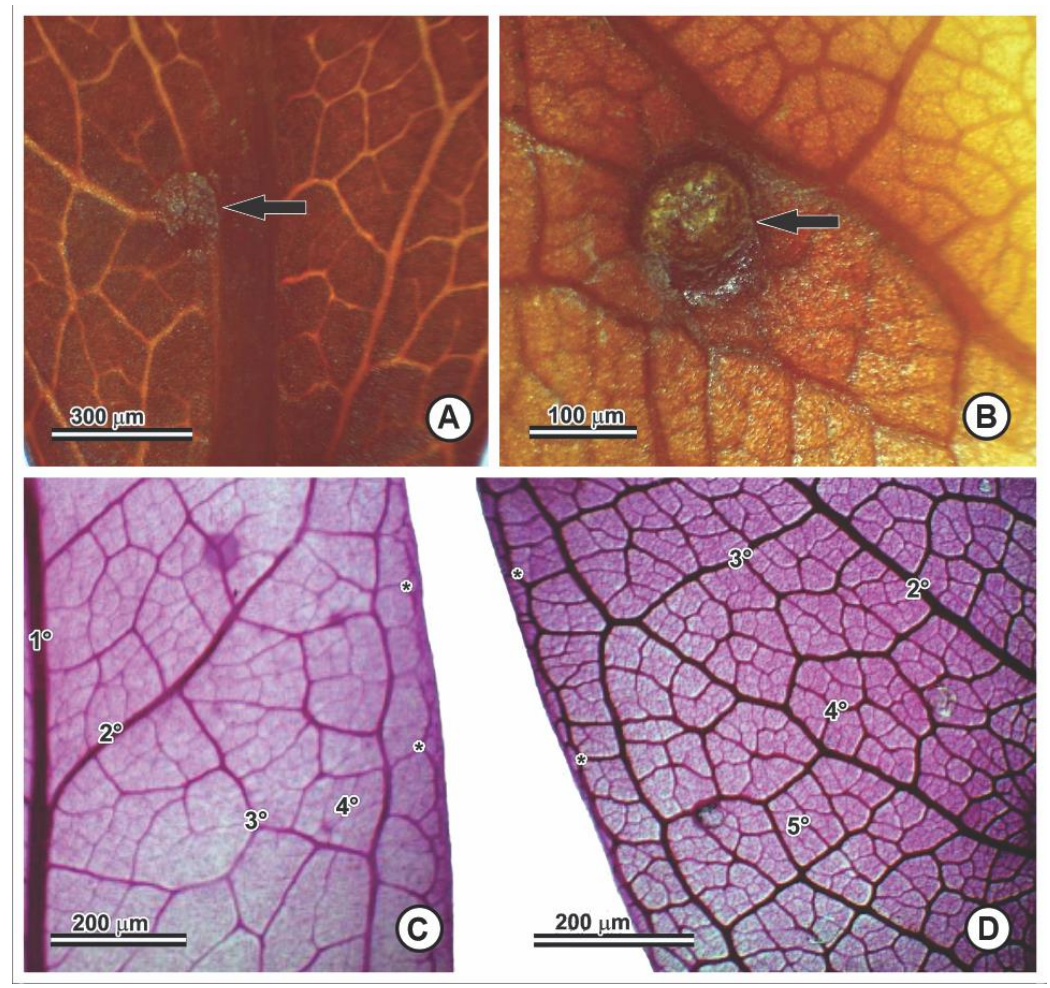

Source: Authors.

\subsection{Identification key for Barnebya species.}

1. A pair of accessory bundles in the petiole, conformation of the vascular bundle of the biconvex midrib vein, trichomes present in the midrib vein, abscence of arrangements in the outer wall of epidermal cells, absence of prismatic crystals, absent sheath extension. B. dispar

1'. Two pairs of accessory bundles in the petiole, conformation of the vascular bundle of the plane-convex midrib vein, trichomes absent in the midrib, presence of arrangements in the outer wall of the epidermal cells, presence of prismatic crystals, extension of the sheath present.......... harleyi

\section{Discussion}

The analyzed individuals did not show variation in relation to the petiole contour or the conformation of its vascular bundle, an important characteristic in distinguishing taxa is used by authors such as Araújo et al. (2010) and Araújo et al. (2020) working with the genera Banisteriopsis, Byrsonima and Heteropterys (Malpighiaceae) and Almeida Jr. et al. (2012) in work with the genus Manilkara (Sapotaceae). Four types of petiole contour have been reported in the literature for 
Malpighiaceae, concave-convex, plane-convex (Araújo et al., 2010), circular and biconvex recently described by Araújo et al. (2020) and Santos et al. (2020) for Banisteriopsis and Byrsonima, respectively. The results obtained in this study corroborate these data and describe the biconvex type for Barnebya.

The number of accessory bundles in the studied species was a useful feature in distinguishing them and has already been used in different botanical families such as Malpighiaceae (Araújo et al., 2010; Almeida et al., 2019; Mello et al., 2019) and Sapotaceae (Almeida Jr. et al., 2012).

The conformation of the vascular bundle in the midrib vein varied and proved to be useful in distinguishing taxa, a characteristic already used in taxonomy by several authors in several families such as Erythroxylaceae (Beiras \& Sajo, 2004), Myrtaceae (Gomes et al., 2009), Sapotaceae (Almeida Jr. et al., 2012), and Malpighiaceae (Araújo et al., 2010; Guimarães et al., 2016; Araújo et al., 2020; Santos et al., 2020).

Malpighiaceous trichomes are described as characteristic in the family and have already been observed by several authors in different genera, although it was not possible to identify the type of trichome in Barnebya's petioles and in the main marrow of B. dispar, the absence or presence of these structures in a taxon have great taxonomic value, (Metcalfe \& Chalk, 1979; Ferreira, 1981; Araújo et al., 2010; Anderson, 2011; Gavilanes, 2020; Feio et al., 2018; Bárcenas-López et al., 2018; Almeida et al. ,2019; Mello et al., 2019; Araújo et al., 2020).

Both in the petiole and in the leaf blade, the presence of a cuticle was observed, described by ecologists as a means of protection against water loss, microbial defense structure and solar incidence (Apezzato et al., 2012; Davis et al., 2010; Bárcenas-López et al., 2018). The presence of druses and single crystals are related to adaptation against herbivory, microbial defense and the development of the pollen tube, since its growth requires intracellular calcium gradients (Metcalfe \& Chalk, 1979; Bárcenas-López et al., 2018). Raven et al., (1976) mention that calcium oxalate is known as an extremely toxic product of plant metabolism and the formation of calcium crystals from oxalate could serve as a way of immobilizing this substance.

The species present glands in the leaf blade, the presence of these structures in representatives of Malpighiaceae is a relevant and common taxonomic characteristic in the family, already described by several authors as Anderson (1981), Mamede (1993), Araújo et al. (2010), Guimarães et al. (2016), Almeida et al. (2017), Almeida et al. (2019) and Matos and Araújo (2021).

The use of anatomy applied to taxonomy has been increasingly used and has proved to be quite useful since the 19th century, combined or not with morphological characters (Solereder, 1908; Metcalfe et al., 1979) and in different botanical families like Malpighiaceae (Araújo et al., 2010; Almeida et al., 2017; Almeida et al., 2019; Mello et al., 2019; Araújo et al., 2020; Santos et al., 2020), Sapotaceae (Almeida Jr. et al. 2012 ), Cyperaceae (Prata et al., 2007), Polygonaceae (Tabosa et al., 2016) and Euphorbiaceae (Feio et al., 2018), a fact proven in the referred work where we were able to describe and distinguish the species of the genus Barnebya using anatomical characteristics.

Among the main characteristics used some of them can be highlighted, such as the number of accessory bundles in the petiole, conformation of the vascular bundle of the midrib, absence or presence of trichomes in the main rib, absence or presence of prismatic crystals and absence or presence of sheath extension. The anatomy of the petiole and characters related to the leaf glands of Barnebya were very conserved at the generic level, and the anatomy of the midrib was informative at the species level, a fact already observed by Araújo et al. (2020) and Santos et al. (2020) for other Malpighiaceae genera.

\section{Conclusions}

This study carried out for the first time the leaf anatomical description of Barnebya and includes the two currently recognized species, increasing the database on the genus and showing that characters related to the morphology of the leaf glands, the anatomy of the petiole and the midrib vein, such as shape, presence and number of accessory bundles and 
conformation of the vascular bundle are important in the characterization of genera and species in Malpighiaceae. In addition to providing data capable of improving the understanding of the relationships between Barnebya species and the other clades of the family, since this relationship is still confusing and poorly understood.

\section{Acknowledgements}

The curators and staff from BHCB, HUEFS, SPF, VIC and VIES herbaria for their assistance; and CNPq Universal Project (grant \#422747/2016-5).

\section{Author Contributions}

Rafael Ribeiro de Matos: Collect, processing and analysis of botanical material, wording of the manuscript; Natania Pereira Pinto da Silva: processing and analysis of botanical material, wording of the manuscript; Josiane Silva Araújo: Analysis of botanical material and wording of the manuscript.

\section{References}

Almeida-Jr, E. B., Araújo, J. S., Santos-Filho, F. S., \& Zicke, C. S. (2012). Leaf morphology and anatomy of Manilkara Adans. (Sapotaceae) from northeastern Brazil. Plant Syst Evol 299:1-9. 10.1007/s00606-012-0697-2.

Almeida, R. F., Guesdon, I. R., Pace, M. R., \& Meira, R. M. S. A. (2019). Taxonomic revision of Mcvaughia W.R.Anderson (Malpighiaceae): notes on vegetative and reproductive anatomy and the description of a new species. PhytoKeys 117: 45-72. 10.3897/phytokeys.117.32207.

Almeida, R. F., Mello, A. C. M. P., Oliveira, D. M. T. O., \& Amorim, A. M. A. (2017). Leaf anatomy and macro-morphology uncover a new species of Amorimia (Malpighiaceae) from Southeastern Brazil. Phytotaxa 305 (3): 179-190. https://doi.org/10.11646/phytotaxa.305.3.5

Anderson, C. E. (2011). Revision of Ryssopterys and transfer to Stigmaphyllon (Malpighiaceae). Blumea 56: 73-104. https://doi.org/10.3767/000651911X573444.

Anderson, W. R., (1979). Floral conservation in Neotropical Malpighiaceae. Biotropica 11: 219-223. Disponível em: https://rcpol.org.br/wpcontent/uploads/2018/02/05.pdf Acesso em: 10 de dezembro de 2021.

Anderson, W. R,. (1981). Malpighiaceae. In The botany of the Guayana Highland-Part XI. Memoirs of the New York Botanical Garden 32: 21-305.

Anderson, W. R., (1993). Chromosome Numbers of Neotropical Malpighiaceae. Contr Univ Michigan Herb 19:341-354.

Anderson, W. R,. \& Gates, B. (1981). Barnebya, a new Genus of Malpighiaceae from Brasil. Brittonia 33(3). https://doi.org/10.2307/2806416.

Apezzato, B. G., \& Carmello, S.M.G. (2012). Anatomia Vegetal. (3a ed.), Editora UFV, 404 p.

Araújo, J. S., Azevedo, A, A., Silva, L. C., \& Meira, R. M. S. A. (2010). Leaf antomy as na additional taxonomy tool for 16 espécies of Malpighiaceae found in the Cerrado área (Brazil). Plant Syst Evol 286: 117. https://doi.org/10.1007/s00606-010-0268-3 .

Araújo, J. S., Almeida, R. F., \& Meira, R. M. S. A. (2020). Taxonomic relevance of leaf anatomy in Baniteriopsis C.B. Rob. (Malpighiaceae). Acta Bot Bras 34(1): 214-228. https://doi.org/10.1590/0102-33062019abb0276.

Bárcenas-López, L., Montaño-Arias, S. A., López-Sandoval, J. A., Huerta, A. G., Rubí-Arriaga, M., \& Simón, G. V. (2019). Foliar anatomy of Malpighia mexicana (Malpighiaceae). Act Bot Mex 126: e1404. https://doi.org/10.21829/abm126.2019.1404.

BFG - Brazilian Flora Group. (2015). Growing knowledge: an overview of Seed Plant diversity in Brazil. Rodriguésia 66: 1085-1113.

Bieras, A. C., \&. Sajo, M. G. (2004). Anatomia foliar de Erythroxylum P. Browne (Erythroxylaceae) do Cerrado do estado de São Paulo Brasil. Acta Bot Bras 18:601-612. https://doi.org/10.1590/S0102-33062004000300018.

Davis, C. C., \& Anderson, W. R. (2010). A complete generic phylogeny of Malpighiaceae inferred from nucleotide sequence data and morphology. Am J Bot 97(12): 2031-2048. https://doi.org/10.3732/ajb.1000146

Ellis, B., Daly, D. C., Hickey, L J., et al. (2009). Manual of leaf architecture. Cornell University Press, 220 p.

Feio, A. C., Meira, R. M. S. A., \& Riina, R. (2018). Leaf anatomical features and their implications for the systematics of dragon's blood, Croton section Cyclostigma (Euphorbiaceae). Bot J Linn Soc 187, 614-632. https://doi.org/10.1093/botlinnean/boy038.

Ferreira, G. L. (1981). Anatomia Foliar de Peixotoa hispidula Juss. (Malpighiaceae). Arquivos do Jardim Botânico do Rio de Janeiro, Vol. XXV, Invêntaíuo Bn 00.210.301-0.

Foster, A. S. (1950). Practical plant anatomy. New York, D. Van Nostrand Company, 228 p. 
Research, Society and Development, v. 11, n. 3, e47011325823, 2022

(CC BY 4.0) | ISSN 2525-3409 | DOI: http://dx.doi.org/10.33448/rsd-v11i3.25823

Gavilanes, M. L., Silva, A. M., Dias, M. V. F., Oliveira, J. Á., Corrêa, F. F., Rodrigues, L. C. A., \& Duarte, V. P. (2020). Leaf structure of Byrsonima coccolobifolia Kunth. (Malpighiaceae) in a savannah and rupestrian field environment. Research, Society and Development, 9(12), e14991210077. 10.33448/rsd-v9i12.10077. https://www.rsdjournal.org/index.php/rsd/article/view/10077.

Gomes, S. M., Somavilla, N. S. D. N., Gomes-Bezerra, K. M., Miranda, S. C., Carvalho, O. S., \& Graciano-Ribeiro, D. (2009). Anatomia foliar de espécies de Myrtaceae: contribuições à taxonomia e filogenia. Acta Bot Bras 23(1): 223-238. https://doi.org/10.1590/S0102-33062009000100024.

Guimarães, A. L. A., Costa, R. P. C., Cabral, L. M., \& Vieira, A. C. M. (2016). Comparative anatomy and chemical analysis of the vegetative organs of three species of Stigmaphyllon (Malpighiaceae). Flora 224 30-41. 10.1016 / j.flora.2016.07.001

Howard, R. A. (1979). The petiole. In: CR Metcalfe, L Chalk Anatomy of the dicotyledons. Vol. 1. Systematic anatomy of the leaf and stem. (2a ed.), Claredon Press Oxford, Oxford, p. 88-96.

Kraus, J. E., \& Arduin, M. (1997). Manual básico de métodos em morfologia vegetal. Editora da Universidade Federal Rural do Rio de Janeiro, 198 p.

Mamede, M. C. H. (1987). Flora da Serra do Cipó, Minas Gerais: Malpighiaceae. Bol Bot Univ 9: 157-198.

Mamede, M. C. H. (1993). Anatomia dos órgãos vegetativos de Camarea (Malpighiaceae). Acta Bot Bras 7 (1). 10.1590/S0102-33061993000100001.

Matos, R. R., \& Araújo, J.S. (2021). Morfoanatomia das glândulas foliares e calicinais de Stigmaphyllon A.Juss. (Malpighiaceae): evidências funcionais, contribuições taxonômicas e evolutivas. Hoehnea 48: e282021. https://doi.org/10.1590/2236-8906-28/2021.

Mello, A. C. M. P., Almeida, R. F., Amorim, A. M. A., \& Oliveira, D. M. T. (2019). Leaf structure in Amorimia and closely related Neotropical genera and implications for their systematics and leaf evolution in Malpighiaceae. Bot J Linn Soc, 191, 102-127. 10.1093/botlinnean/boz028.

Metcalfe, C. R., \& Chalk, L. (1979). Anatomy of the dicotyledons. Systematic anatomy of the leaf and stem. Oxford Claredon Press, Oxford, $288 \mathrm{p}$.

Prata, A. P., Menezes, N. L., Mazzoni-Viveiros, S. C., Wanderley, M. G. L., \& Thomas, W. W. (2007). Anatomia do escapo e rizoma de espécies brasileiras de Bulbostylis Kunth (Cyperaceae). Rev Bras Bot V.30, n.2, p.245-256. https://doi.org/10.1590/S0100-84042007000200009

Raven, J. A., \& Smith, F. A. (1976). Nitrogen assimilation and transport in vascular land plants in relation to intracellular pH regulation. New Phytol p. 415431. https://doi.org/10.1111/j.1469-8137.1976.tb01477.x

Santos, J. V. C., Oliveira, M. F. V., Santos-Filho, S. F., Silva, L. N. N. S., \& Araújo, J. S. (2020). The taxonomic value of leaf anatomy for species Byrsonima: a difficult genus of Malpighiaceae Juss. Acta Bot Bras 34(3). http://dx.doi.org/10.1590/0102-33062020abb0144.

Solereder, H. (1908). Systematic Anatomy of the Dicotyledons: A Handbook for Laboratories of Pure and Applied Botany. 2, Clarendon Press, Oxford.

Tabosa, F. R. S., Almeida, E. M., Melo, E., \& Loiola, M. I. B. (2016). Flora do Ceará, Brasil: Polygonaceae. Rodriguésia 67(4): 981-996. https://doi.org/10.1590/2175-7860201667409

Theobald, W. L., Krahulik, J. L., \& Rollins, R. C. (1979). Trichome description and classification. In: Metcalf CR, Chalk L, Anatomy of the dicotyledons. Systematic anatomy of the leaf and stem. Oxford: Oxford Claredon Press. http://dx.doi.org/10.1007/s00606-014-1037-5

Thiers, B. (2019). Index Herbariorum: A global directory of public herbaria and associated staff. New York, New York Botanical Garden's Virtual Herbarium. http://sweetgum.nybg.org/ih/ 